\title{
Effect of Hydrogen, Sucrose and Oxygen on Uptake Hydrogenase in Nitrogen-fixing and Ammonium-grown Pseudomonas saccharophila ATCC 15946
}

\author{
By WILFREDO L. BARRAQUIO AND ROGER KNOWLES* \\ Department of Microbiology, Macdonald College of McGill University, 21111 Lakeshore Road, \\ Ste Anne de Bellevue, PQ H9X 1CO Canada
}

(Received 13 July 1987; revised 10 November 1987)

Pseudomonas saccharophila, grown microaerobically in batch culture, showed much higher uptake hydrogenase activity in $\mathrm{N}_{2}$-fixing than in $\mathrm{NH}_{4}^{+}$-grown cultures. Hydrogenase synthesis was induced by $\mathrm{H}_{2}$ under a low partial pressure of $\mathrm{O}_{2}$ and under air, in autotrophic as well as in heterotrophic conditions, provided that the sucrose concentration was relatively low. Sucrose at $15 \mathrm{~mm}$ repressed hydrogenase formation but did not inhibit preformed activity. Other utilizable carbon substrates repressed, while non-utilizable substrates did not repress, hydrogenase synthesis. The activity, unlike nitrogenase, was not sensitive to $\mathrm{O}_{2}$ but hydrogenase synthesis was partially repressed by $\mathrm{O}_{2}$.

\section{INTRODUCTION}

Pseudomonas saccharophila is a facultative chemoautotroph which was isolated by $\mathrm{H}_{2} / \mathrm{CO}_{2} / \mathrm{O}_{2}$ enrichment from the mud of a stagnant pool; so far only one strain of the species is known (Doudoroff, 1940; Palleroni, 1984). Recently, some isolates from surface sediment of freshwater lakes were assigned to $P$. saccharophila (Schink \& Zeikus, 1984) but further characterization is needed to verify their identity. The autotrophic and heterotrophic metabolism of $P$. saccharophila has long received attention (e.g. Donawa et al., 1971; Doudoroff, 1940; Palleroni, 1956), but its ability to fix $N_{2}$ was not critically examined and it was thus reported as non- $\mathrm{N}_{2}-$ fixing (Palleroni, 1984). Recently, we found that among the known hydrogen pseudomonads tested only $P$. saccharophila could fix $\mathrm{N}_{2}$, and that it does so under both heterotrophic and autotrophic conditions (Barraquio et al., 1986).

Nitrogenase catalyses not only $\mathrm{N}_{2}$ reduction but also ATP-dependent $\mathrm{H}_{2}$ evolution: The oxidation of evolved $\mathrm{H}_{2}$ by a $\mathrm{N}_{2}$-fixing culture may recover some of the energy lost through $\mathrm{H}_{2}$ production, may prevent inhibition of nitrogenase by hydrogen, and may provide protection to nitrogenase by removal of excess oxygen (Dixon, 1972). Such $\mathrm{H}_{2}$ recycling occurs in Azotobacter chroococcum (Walker \& Yates, 1978), Rhizobium japonicum (Emerich et al., 1979) and Rhizobium leguminosarum bacteroids (Salminen \& Nelson, 1984). Uptake hydrogenase, the enzyme responsible for the unidirectional conversion of molecular $\mathrm{H}_{2}$ to protons, is found in several other diazotrophic genera (e.g. Azospirillum, Alcaligenes, Derxia and Xanthobacter) (Bowien \& Schlegel, 1981). The hydrogenase system of these organisms, however, is regulated differently by $\mathrm{O}_{2}$ and $\mathrm{H}_{2}$, and by carbon and nitrogen sources.

It was suggested that since $P$. saccharophila can utilize $\mathrm{H}_{2}$ as an electron donor during chemoautotrophic $\mathrm{N}_{2}$-fixation, it may have the ability to utilize the $\mathrm{H}_{2}$ evolved during heterotrophic $\mathrm{N}_{2}$-fixation (Barraquio et al., 1986). We report here the presence of an active uptake hydrogenase in $P$. saccharophila during heterotrophic $\mathrm{N}_{2}$-fixation, and the regulation of its activity and synthesis by $\mathrm{H}_{2}$, sucrose and $\mathrm{O}_{2}$.

Abbreviations: CM, chloramphenicol; MB, methylene blue; PMSF, phenylmethylsulphonyl fluoride. 


\section{METHODS}

Organism and growth. The bacterial strain used in this study, $P$. saccharophila ATCC 15946, was the same culture as used previously (Barraquio et al., 1986). Stock cultures were kept in screw-cap $4 \mathrm{ml}$ vials containing $0.5 \mathrm{ml}$ dense cell suspension and $0.5 \mathrm{ml}$ half-strength Difco nutrient broth plus glycerol $(10 \%, \mathrm{v} / \mathrm{v})$ at $-80{ }^{\circ} \mathrm{C}$. A new stock culture was used for each experiment.

For inocula and batch cultures we used the mineral salts plus sucrose $(0 \cdot 1 \%)$ plus $\mathrm{NH}_{4} \mathrm{Cl}(0 \cdot 1 \%)$ medium described by Barraquio et al. (1986), except that the phosphate concentration was reduced from $50 \mathrm{mM}$ to $16.7 \mathrm{mM}$ and $\mathrm{CaCl}_{2} .2 \mathrm{H}_{2} \mathrm{O}$ was reduced from $0 \cdot 2$ to $0.02 \mathrm{~g} \mathrm{l}^{-1}$. The $\mathrm{pH}$ of the medium was $6 \cdot 8 . \mathrm{NH}_{4} \mathrm{Cl}$ was omitted in the nitrogen-deficient medium. Yeast extract was routinely added at $0.01 \%(\mathrm{w} / \mathrm{v})$ to both the nitrogen-deficient and the $\mathrm{NH}_{4}^{+}$-containing media (see Results). $\mathrm{CaCl}_{2}, \mathrm{MgSO}_{4}$ and sucrose solutions were autoclaved separately and added to the cooled medium.

A colony from a plate (half-strength Difco nutrient broth solidified with $1.5 \%$, w/v, agar) was transferred into $10 \mathrm{ml}$ of culture medium which was incubated on a gyratory shaker $\left(250\right.$ r.p.m.) for $24 \mathrm{~h}$ at $30^{\circ} \mathrm{C}$. A sample $(5 \mathrm{ml})$ was transferred into $50 \mathrm{ml}$ of the same medium in a $250 \mathrm{ml}$ flask, and then shaken for $12 \mathrm{~h}$. The cells were harvested by centrifugation $(10000 \mathrm{~g}$ for $10 \mathrm{~min})$, washed three times with culture medium and finally suspended in $10-20 \mathrm{ml}$ of the same medium.

Batch culture medium $(950 \mathrm{ml})$ was inoculated with $9.5 \mathrm{ml}$ of the washed cells, then sparged at $450 \mathrm{ml} \mathrm{min}^{-1}$ with a cotton-filtered mixture of 0.71 to $1.0 \%(\mathrm{v} / \mathrm{v}) \mathrm{O}_{2}$ in $\mathrm{N}_{2}$. Hydrogen gas was used at $2.2 \%$ of the gas phase. The culture was incubated at $30^{\circ} \mathrm{C}$ and continuously stirred by a Teflon-coated magnetic bar. Culture samples were withdrawn from the culture flask through a Suba-seal-plugged bottom port using a $10 \mathrm{ml}$ syringe. At the end of each experiment, the culture was checked for purity by plating on nutrient agar. Most gases were obtained from Linde (Union Carbide Canada); mixing of $\mathrm{H}_{2}, \mathrm{O}_{2}$ and $\mathrm{N}_{2}$ was done by using flowmeters in the laboratory. Some $\mathrm{O}_{2} / \mathrm{N}_{2}$ mixtures were purchased from Liquid Carbonic Canada. Compositions of gas mixtures are given throughout as $\%(\mathrm{v} / \mathrm{v})$.

Uptake hydrogenase assay. Hydrogen uptake was measured by the $\mathrm{O}_{2}$-dependent $\mathrm{H}^{3} \mathrm{H}$ uptake method as described by Tibelius \& Knowles (1983) using $2 \mathrm{ml}$ culture samples in $14 \mathrm{ml}$ vials with silicone-reinforced butyl rubber caps for $30 \mathrm{~min}$ at $30^{\circ} \mathrm{C} . \mathrm{H}^{3} \mathrm{H}$ was added at $3 \%$ of the gas phase and $\mathrm{O}_{2}$ was added as indicated. $\mathrm{H}^{3} \mathrm{H}$ had a specific activity of 19.9 to $20.6 \mu \mathrm{Ci} \mathrm{m}^{-1}$ (736 to $762 \mathrm{kBq} \mathrm{ml}^{-1}$ ) and was obtained from Gollob Analytical Service. Methylene blue (MB) at $5 \mathrm{mM}$ was also used as an electron acceptor. The MB (J. T. Baker Chemicals), dissolved in phosphate buffer ( $\mathrm{pH} \mathrm{6.8),} \mathrm{was} \mathrm{kept} \mathrm{in} \mathrm{vials} \mathrm{which} \mathrm{were} \mathrm{evacuated} \mathrm{and} \mathrm{backfilled} \mathrm{three} \mathrm{times} \mathrm{with} \mathrm{N}_{2}$, and was added by $\mathrm{N}_{2}$-flushed syringe into $\mathrm{N}_{2}$-prefilled vials containing the culture samples. Assays were started by removing $3 \%$ of the gas phase and replacing it with $\mathrm{H}^{3} \mathrm{H}$. Incubation time was $20-30 \mathrm{~min}$.

Acetylene reduction assay. Nitrogenase activity was measured by the acetylene reduction method in $2 \mathrm{ml}$ culture samples contained in $14 \mathrm{ml}$ vials. The assay was done using a gas phase of $5 \% \mathrm{C}_{2} \mathrm{H}_{2}$ and $\mathrm{O}_{2}$ as indicated in $\mathrm{He}$ for $1 \mathrm{~h}$ at $30^{\circ} \mathrm{C}$ on a gyratory shaker $(250$ r.p.m.).

Analyses. $\mathrm{H}_{2}$ and $\mathrm{O}_{2}$ were measured by gas chromatography as described by Chan et al. (1980) and $\mathrm{C}_{2} \mathrm{H}_{4}$ as described by Tibelius \& Knowles (1983). Optical density was measured at $430 \mathrm{~nm}$ with a Bausch and Lomb Spectronic 20. Protein of washed cells was estimated by the Lowry method as previously described (Barraquio et al., 1986) or by the modified method of Markwell et al. (1978). Reducing sugar was determined by the phenol method (Herbert et al., 1971) using sucrose as the standard. Dissolved $\mathrm{H}_{2}$ and $\mathrm{C}_{2} \mathrm{H}_{4}$ were calculated using the appropriate Ostwald coefficients (Wilhelm et al., 1977).

\section{RESULTS}

\section{$K_{\mathrm{m}}$ for $\mathrm{H}_{2}$ of uptake hydrogenase}

The apparent $K_{\mathrm{m}}$ for $\mathrm{H}_{2}$ of hydrogenase was determined in whole cells of a stationary phase $\mathrm{N}_{2}$-fixing culture. From an Eadie-Hofstee plot, the apparent $K_{\mathrm{m}}$ for $\mathrm{H}_{2}$ in the $\mathrm{O}_{2}$ - and MBdependent assays was $4.3 \mu \mathrm{M}$ and $1.82 \mu \mathrm{M}$ in solution, respectively. In the gas phase, these values correspond to $0.56 \%$ and $0.24 \%(\mathrm{v} / \mathrm{v})$ for $\mathrm{O}_{2}$ - and $\mathrm{MB}$-dependent activities, respectively. These values are lower than that for Azospirillum brasilense which was 1.2 to $3 \%$ (Pedrosa et al., 1982; Tibelius \& Knowles, 1983). The value for MB-dependent activity is similar to that for $R$. japonicum which was $0.23 \%$ ( $\mathrm{Lim} \&$ Shanmugam, 1979). The $\mathrm{H}^{3} \mathrm{H}$ concentration used in this study $(3 \%)$ was sufficient to saturate the $\mathrm{O}_{2}$ - and $\mathrm{MB}$-dependent components of the hydrogenase system; in both cases the uptake of $\mathrm{H}^{3} \mathrm{H}$ was linear with time up to about 90 min (data not shown). 


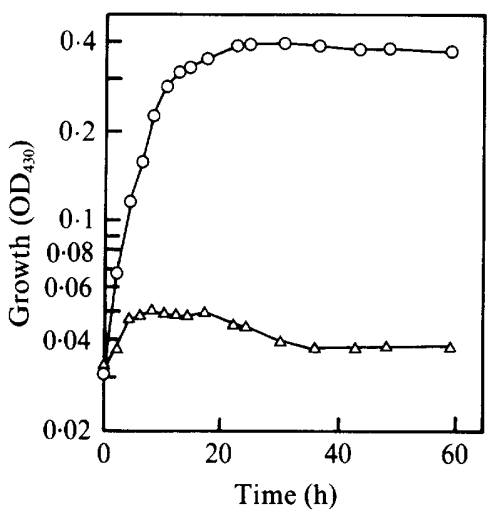

Fig. 1
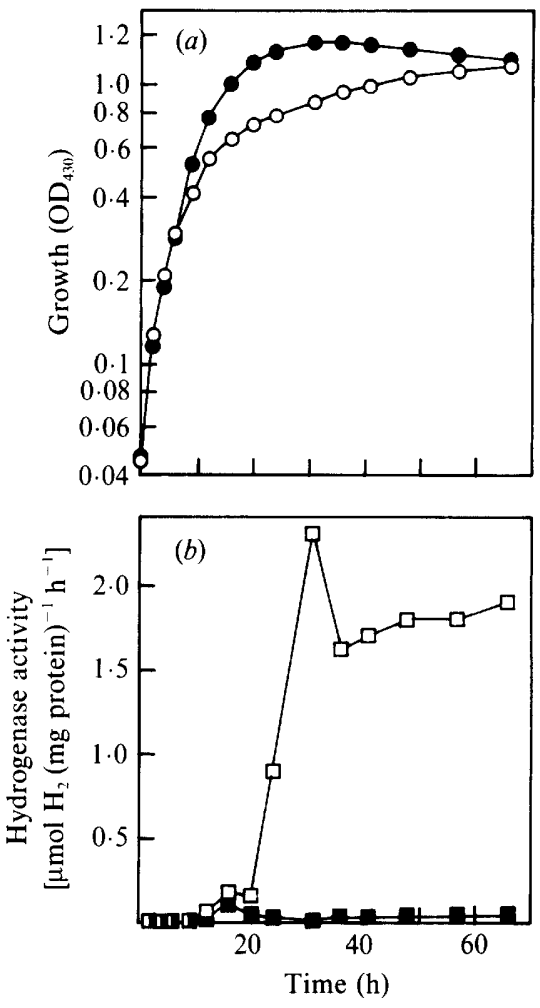

Fig. 2

Fig. 1. Effect of yeast extract on growth of $P$. saccharophila under $\mathbf{N}_{2}$-fixing conditions. The organism was grown with shaking at $30^{\circ} \mathrm{C}$ in $125 \mathrm{ml}$ side-arm flasks each containing $15 \mathrm{ml}$ of nitrogen-deficient medium plus $(\mathrm{O})$ or minus $(\triangle) 0.01 \%(\mathrm{w} / \mathrm{v})$ Difco yeast extract in an atmosphere of $0.80 \% \mathrm{O}_{2}$ in $\mathrm{N}_{2}$. Data are the average of five replicate flasks.

Fig. 2. Growth (a) and hydrogenase activity (b) of $P$. saccharophila under $\mathrm{N}_{2}$-fixing (open symbols) and $\mathrm{NH}_{4}^{+}$-grown (closed symbols) conditions. Both cultures were grown under $0.713 \% \mathrm{O}_{2}$ in $\mathrm{N}_{2}$. MB was used as the electron acceptor in the hydrogenase assay.

\section{Growth and $\mathrm{H}_{2}$ oxidation under $\mathrm{N}_{2}$-fixing and non- $\mathrm{N}_{2}$-fixing conditions}

$P$. saccharophila ATCC 15946 showed negligible growth unless supplemented with Difco yeast extract (Fig. 1), although both supplemented and unsupplemented cultures showed nitrogenase activity (data not shown).

The growth rates in both $\mathrm{N}_{2}$-fixing and $\mathrm{NH}_{4}^{+}$-grown microaerobic cultures were practically the same in the first $6 \mathrm{~h}$ (Fig. $2 a$ ), no doubt due to the initial utilization of the yeast extract. Thereafter, the $\mathrm{N}_{2}$-fixing culture grew relatively slowly, but during this period a marked increase in hydrogenase activity in this culture was observed (Fig. 2b). Activity was very much higher in the $\mathrm{N}_{2}$-fixing culture than in the $\mathrm{NH}_{4}^{+}$-grown culture.

\section{Hydrogenase induction}

The results of the above experiment could indicate that the $\mathrm{H}_{2}$ evolved during $\mathrm{N}_{2}$ fixation stimulated synthesis of hydrogenase. We therefore determined if such synthesis could be induced by exogenous $\mathrm{H}_{2}$. Indeed, the level of hydrogenase under non- $\mathrm{N}_{2}$-fixing autotrophic conditions increased greatly in the presence of $\mathrm{H}_{2}$ (Fig. 3). Addition of chloramphenicol $(\mathrm{Cm})$ prevented the increase. The results suggest that the $\mathrm{H}_{2}$ did not activate preformed enzyme but 


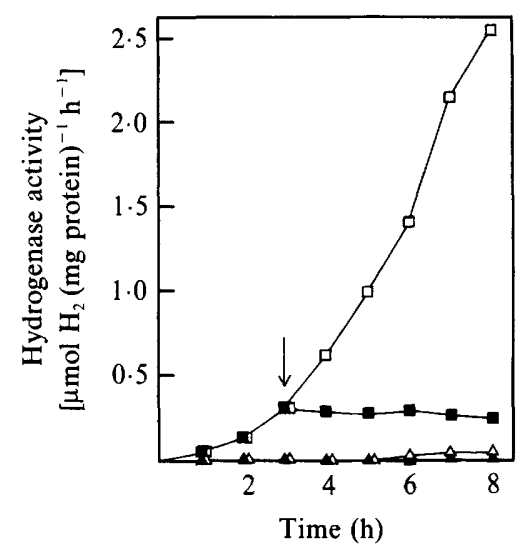

Fig. 3
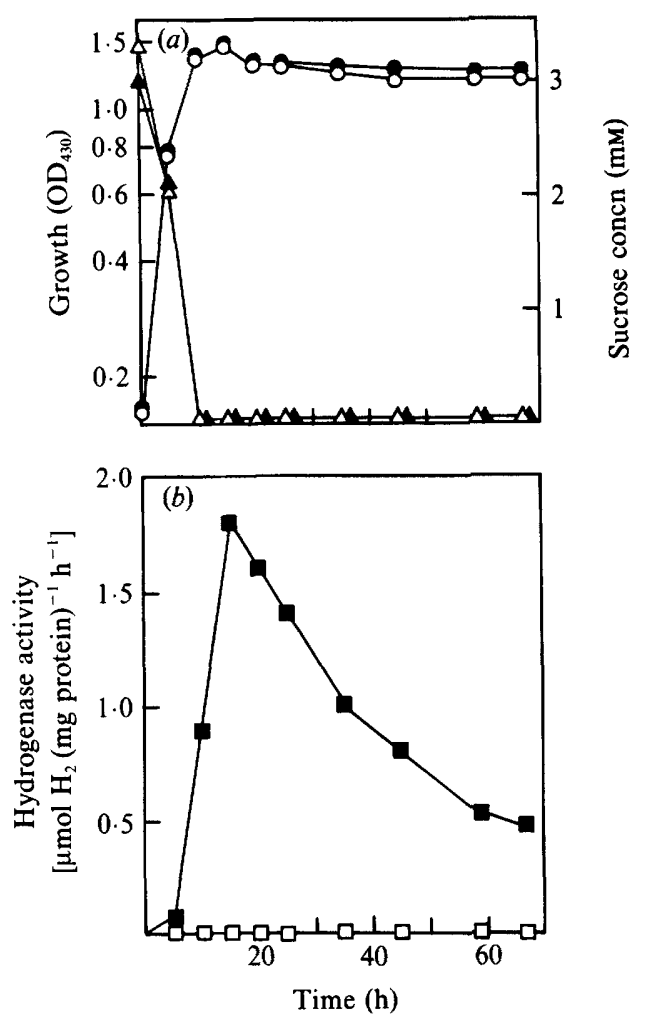

Fig. 4

Fig. 3. Effect of $\mathrm{H}_{2}$ on hydrogenase synthesis in $P$. saccharophila. A mid-exponential phase, $\mathrm{NH}_{4}^{+}-$ grown heterotrophic culture was washed, and then resuspended in a small quantity of the same medium but without sucrose. Samples $\left(5 \mathrm{ml}, \mathrm{OD}_{430}=18,1.5 \mathrm{mg}\right.$ protein $\mathrm{ml}^{-1}$ ) were inoculated into $500 \mathrm{ml}$ vacuum flasks each containing $150 \mathrm{ml}$ of the same medium. Zero-time samples were taken, and then the flasks were evacuated and backfilled with $\mathrm{N}_{2} ; 20 \%$ of the headspace was withdrawn then replaced individually with $5 \% \mathrm{CO}_{2}, 5 \% \mathrm{O}_{2}$ and $10 \% \mathrm{H}_{2}$ or $\mathrm{Ar}$. $\mathrm{Cm}\left(100 \mu \mathrm{g} \mathrm{ml} \mathrm{l}^{-1}\right)$ was added as indicated (arrow). The flasks were shaken at $30^{\circ} \mathrm{C}$, and samples were taken each hour. Hydrogenase assays were done under air. The treatments were: plus $\mathrm{H}_{2}(\square)$, plus $\mathrm{H}_{2}$ and $\mathrm{Cm}(\square)$, plus $\operatorname{Ar}(\triangle)$, and plus $\operatorname{Ar}$ and $\mathrm{Cm}$ $(\boldsymbol{A})$. Data are the average of triplicate samples.

Fig. 4. Growth and hydrogenase activity of $P$. saccharophila with (closed symbols) and without (open symbols) $\mathrm{H}_{2}(2 \cdot 2 \%)$ under non- $\mathrm{N}_{2}$-fixing conditions (aerobically with $\left.\mathrm{NH}_{4} \mathrm{Cl}\right)$. (a) Growth $(\mathrm{O}, \mathrm{O})$ and residual reducing sugar as sucrose $(\triangle, \Delta)$. (b) Hydrogenase activity. Activity was measured using $2 \%$ $\mathrm{O}_{2}$ as the electron acceptor. Data are the average of triplicate samples for residual sucrose and hydrogenase activity.

rather caused derepression of synthesis of hydrogenase. Cultures supplied with Ar instead of $\mathrm{H}_{2}$ had very low or negligible activity (Fig. 3 ).

We then determined if synthesis of hydrogenase could be induced by $\mathrm{H}_{2}$ under aerobic heterotrophic conditions. $\mathrm{NH}_{4}^{+}$-grown batch cultures were sparged with air alone or with air containing $2 \cdot 2 \% \mathrm{H}_{2}$. The growth and sucrose-utilization patterns were nearly identical for both cultures (Fig. $4 a$ ). However, the hydrogenase activity remained negligible in the absence of exogenous $\mathrm{H}_{2}$ (Fig. $4 b$ ). In contrast, the $\mathrm{H}_{2}$-sparged culture had much higher hydrogenase activity and the maximum activity was reached when the concentration of sucrose in the medium was relatively low. In this experiment, MB-dependent hydrogenase was compared with $\mathrm{O}_{2}$-dependent activity at different growth stages of the $\mathrm{H}_{2}$-sparged culture. MB-dependent hydrogenase activity was higher than the $\mathrm{O}_{2}$-dependent activity by $1.6 \pm 0.18$ times (average \pm SEM of determinations from nine time intervals). A similar ratio was obtained by Berndt \& 
Table 1. Effect of different carbon sources on formation of hydrogenase in P. saccharophila previously grown under $\mathrm{N}_{2}$-fixing conditions

\begin{abstract}
A mid-exponential phase $\mathrm{N}_{2}$-fixing culture was washed three times with nitrogen-free medium lacking carbon source. The pellet was resuspended in the same medium, and then $0.2 \mathrm{ml}$ samples of the concentrated cell suspension $\left(\mathrm{OD}_{430}=8,0.56 \mathrm{mg}\right.$ protein $\left.\mathrm{ml}^{-1}\right)$ were dispensed into $14 \mathrm{ml}$ vials containing $1.8 \mathrm{ml}$ of the same medium plus or minus carbon source $(15 \mathrm{~mm})$. The vials were stoppered then evacuated and backfilled three times with $\mathrm{N}_{2}$. Zero-time samples were then assayed for hydrogenase activity using $2 \% \mathrm{O}_{2}$ as the electron acceptor. The gas phase of the remaining vials contained: $5 \% \mathrm{O}_{2}, 5 \% \mathrm{CO}_{2}, 10 \% \mathrm{H}_{2}$, and the balance $\mathrm{N}_{2}$. The vials were shaken for $13 \mathrm{~h}$ at $30^{\circ} \mathrm{C}$ after which cultures were assayed for hydrogenase activity. Data are the average of two replicates (except control and no $\mathrm{CO}_{2}$ treatments which had four replicates each) $\pm \mathrm{SEM}$.
\end{abstract}

\section{Carbon source}

None (control)
D(+)-Fructose
D(+)-Mannose
D(+)-Xylose
D(+)-Glucose
Sodium pyruvate
Sodium citrate
L $(+)$-Arabinose
Sucrose
Sodium acetate
Sodium succinate
D(+)-Galactose
Sodium malate
None, no $\mathrm{CO}_{2}$ (replaced by $\mathrm{Ar}$ )

$\Delta$ Hydrogenase activity*

[(activity at $13 \mathrm{~h})-($ activity at $0 \mathrm{~h}) ; \quad$ Relative nmol $\mathrm{H}_{2}$ (mg protein $\left.)^{-1} \mathrm{~h}^{-1}\right] \quad$ activity

$\begin{array}{cc}7414 \pm 1891 & 100 \\ 9589 \pm 828 & 129 \\ 8477 \pm 790 & 114 \\ 4939 \pm 569 & 67 \\ 4630 \pm 568 & 62 \\ 1489 \pm 106 & 20 \\ 223 \pm 44 & 3 \\ 133 \pm 10 & 1 \cdot 8 \\ 89 \pm 26 & 1 \cdot 2 \\ 53 \pm 5 & 0 \cdot 7 \\ 20 \pm 20 & 0 \cdot 2 \\ 4 \pm 1 \cdot 4 & 0 \cdot 05 \\ 0 & 0 \\ 6063 \pm 1450 & 82\end{array}$

* Zero-time activity in all treatments ranged from 22 to $81 \mathrm{nmol} \mathrm{H}_{2}$ (mg protein) $)^{-1} \mathrm{~h}^{-1}$ with an average of $44 \pm 6$.

Wölfle (1978) in Xanthobacter autotrophicus. The results might suggest that in the $\mathrm{O}_{2}$-dependent assay, some components of the electron transport chain were limiting. The $\mathrm{O}_{2}-$ and $\mathrm{MB}-$ dependent hydrogenase activities at different growth stages were proportional with a correlation coefficient of 0.94 .

\title{
Effect of carbon sources on hydrogenase activity and synthesis
}

The results of the previous experiments suggested that the concentration of sucrose may affect hydrogenase formation. Carbon substrates which are used to different extents for growth of $P$. saccharophila (Barraquio et al., 1986) were therefore examined for their effects on hydrogenase formation. Carbon sources which are utilized only slightly or not at all, such as mannose, fructose, xylose and glucose, repressed hydrogenase formation either not at all or at the most by $40 \%$ (Table 1). Pyruvate, a better substrate, showed $80 \%$ repression. Those carbon sources which support vigorous growth of the organism exhibited $97-100 \%$ repression. In the absence of carbon source, and with $\mathrm{CO}_{2}$ replaced by $\mathrm{Ar}$, there was about a $20 \%$ reduction in hydrogenase expression.

The kinetics of repression of hydrogenase synthesis and of inhibition of preformed enzyme by sucrose were then studied. In the presence of sucrose, preformed hydrogenase activity was not affected but synthesis was almost completely repressed throughout the $8 \mathrm{~h}$ experiment (Fig. 5). Hydrogenase formation was greatly stimulated in the absence of sucrose. In the absence of sucrose but with $\mathrm{Cm}$ there was a rapid decline in activity. Sodium azide prevented this decline whereas phenylmethylsulphonyl fluoride (PMSF) did so only partially.

\section{Effect of $\mathrm{O}_{2}$ on nitrogenase and hydrogenase activity and synthesis}

$\mathrm{N}_{2}$-fixing cultures showed maximum nitrogenase and hydrogenase activities in the exponential and stationary phases, respectively (Fig. 6). Maximum nitrogenase activities were shown at $\mathrm{pO}_{2} 0.0025$ to $0.0050 \mathrm{~atm}$ depending on the growth phase (Fig. $6 a$ ), and activity was 


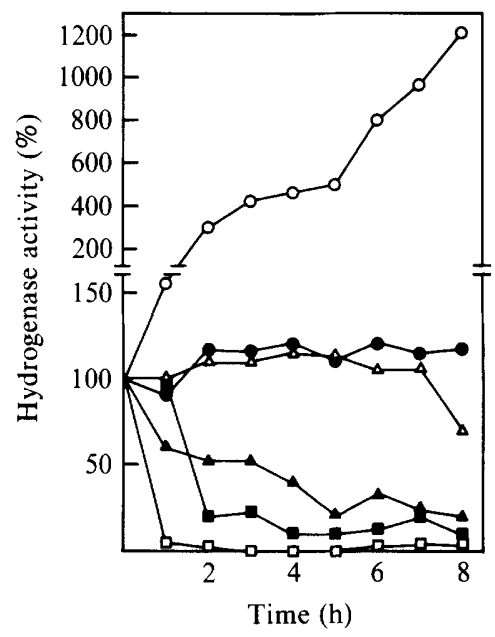

Fig. 5
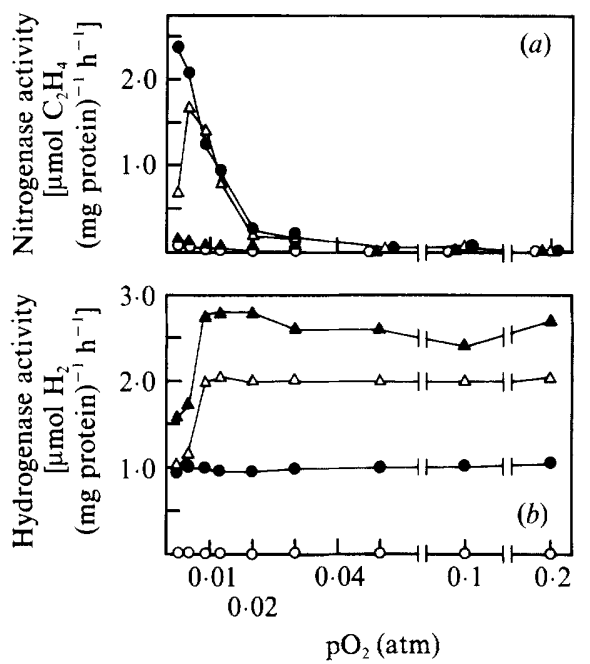

Fig. 6

Fig. 5. Effect of sucrose on preformed activity and synthesis of hydrogenase in $P$. saccharophila. A lateexponential phase, $\mathrm{N}_{2}$-fixing culture was washed, then resuspended in a small quantity of $\mathrm{NH}_{4} \mathrm{Cl}$ containing (minus sucrose) medium. Samples $\left(5 \mathrm{ml}, \mathrm{OD}_{430}=12.4,0.86 \mathrm{mg}\right.$ protein $\mathrm{ml}^{-1}$ ) were inoculated into $500 \mathrm{ml}$ vacuum flasks each containing $150 \mathrm{ml}$ of the same medium. Zero-time samples were taken, then sucrose (15 mM), sodium azide (1 mM), PMSF (1 mM) and Cm $\left(100 \mu \mathrm{g} \mathrm{ml}^{-1}\right)$ were injected immediately as desired. The flasks were evacuated and backfilled with $\mathrm{N}_{2} ; 20 \%$ of the headspace was then withdrawn and replaced individually with $10 \% \mathrm{H}_{2}, 5 \% \mathrm{CO}_{2}$ and $5 \% \mathrm{O}_{2}$. The flasks were shaken at $30^{\circ} \mathrm{C}$, and samples were taken each hour. $\mathrm{MB}$ was used as the electron acceptor in the hydrogenase assay. The treatments were: minus sucrose $(O)$, plus sucrose $(O)$, minus sucrose plus $\mathrm{Cm}$ $(\square)$, plus sucrose and $\mathrm{Cm}(\boldsymbol{\square})$, minus sucrose plus $\mathrm{Cm}$ and sodium azide $(\triangle)$, and minus sucrose plus $\mathrm{Cm}$ and PMSF ( $\mathbf{\Delta})$. Data are the average of triplicate samples.

Fig. 6. $\mathrm{O}_{2}$ optima for nitrogenase $(a)$ and hydrogenase $(b)$ activities of $P$. saccharophila. Activities were measured using early exponential $(O)$, mid-exponential $(O)$, late-exponential $(\triangle)$ and early stationary (A) phase culture samples. Results are the average of triplicates.

\section{Table 2. Effect of $\mathrm{O}_{2}$ on formation of hydrogenase in $\mathrm{P}$. saccharophila}

A mid-exponential phase, $\mathrm{NH}_{4}^{+}$-grown aerobic heterotrophic culture was washed then resuspended in a small quantity of $\mathrm{NH}_{4} \mathrm{Cl}$-containing (minus sucrose) medium. Samples $\left(0.2 \mathrm{ml}, \mathrm{OD}_{430}=6,0.50 \mathrm{mg}\right.$ protein $\mathrm{ml}^{-1}$ ) were dispensed into vials containing $1.8 \mathrm{ml}$ of the same medium without or with sucrose (15 mM). One set of vials received $10 \% \mathrm{H}_{2}, 5 \% \mathrm{CO}_{2}, 2 \cdot 8 \% \mathrm{O}_{2}$, and the balance $\mathrm{N}_{2} ;$ the other set received $10 \% \mathrm{H}_{2}$ and $5 \% \mathrm{CO}_{2}$ in air. The cultures were shaken for $8 \mathrm{~h}$, after which they were analysed for $\mathrm{O}_{2}$, then evacuated and backfilled with $\mathrm{N}_{2}$. The $\mathrm{H}_{2}$-uptake assay was done with $\mathrm{MB}$ as electron acceptor. Values in parentheses are percentage $\mathrm{O}_{2}$ at the end of the derepression period. Data are the average of four replicate samples \pm SEM.

$\begin{array}{ccc}\text { Oxygen (\%) } & \overbrace{\text { Minus sucrose }}^{\left.\text {[nmol } \mathrm{H}_{2}(\mathrm{mg} \text { protein })^{-1} \mathrm{~h}^{-1}\right]} \\ 2.80 & 2107 \pm 288(2 \cdot 43 \pm 0 \cdot 18) & 12 \pm 2(0 \cdot 21 \pm 0 \cdot 05) \\ 18.26 & 443 \pm 32(15 \cdot 80 \pm 0 \cdot 05) & 22 \pm 1(5 \cdot 80 \pm 0 \cdot 19)\end{array}$

observed at all growth phases tested. The hydrogenase showed wide tolerance to $\mathrm{O}_{2}$, maximum activity being observed from $\mathrm{pO}_{2} 0.009$ to $0.2 \mathrm{~atm}$ (Fig. $6 \mathrm{a}$ ). Early exponential cultures did not show hydrogenase activity. Low $\mathrm{pO}_{2}$ values became limiting in late-exponential and early stationary phases but not in mid-exponential phase, probably because of the low hydrogenase activity in the latter. 
It is possible that $\mathrm{O}_{2}$ may become limiting when sucrose is available in the medium, thus causing a low level of hydrogenase synthesis (P. van Berkum, personal communication). To test this hypothesis, hydrogenase formation was induced under microaerobic and aerobic conditions in the presence and absence of sucrose. In the absence of sucrose, hydrogenase formation was partially repressed by $18 \% \mathrm{O}_{2}$, the activity being $80 \%$ lower than that under $2.8 \% \mathrm{O}_{2}$ (Table 2 ). In the presence of sucrose, much lower activity developed. $\mathrm{O}_{2}$ may have been limiting in the $2.8 \% \mathrm{O}_{2}$ plus sucrose treatment but since $5.8 \% \mathrm{O}_{2}$ remained in the $18 \% \mathrm{O}_{2}$ treatment with little appearance of activity, it is probable that sucrose and not $\mathrm{O}_{2}$ availability was the important factor.

\section{DISCUSSION}

$P$. saccharophila was reported to have only a membrane-bound hydrogenase, the formation of which was demonstrated under non- $\mathrm{N}_{2}$-fixing autotrophic conditions (Podzuweit et al., 1983), and although a soluble hydrogenase was reported (Bone, 1960) the finding has not been confirmed. After demonstrating that $P$. saccharophila can fix $\mathrm{N}_{2}$ (Barraquio et al., 1986) our present data clearly show the presence of an active uptake hydrogenase in $\mathrm{N}_{2}$-fixing cultures of this organism. Hydrogenase was expressed significantly more in $\mathrm{N}_{2}$-fixing than in non- $\mathrm{N}_{2}-$ fixing culture, as in Azotobacter chroococcum (Partridge et al., 1980), Xanthobacter autotrophicus (Berndt \& Wölfle, 1978) and Azotobacter vinelandii (Lee \& Wilson, 1943) but in contrast to Azospirillum brasilense where an $\mathrm{NH}_{4}^{+}$-grown culture had hydrogenase activity similar to, or slightly higher than, that in a $\mathrm{N}_{2}$-fixing culture (Tibelius \& Knowles, 1983). Our results show that $\mathrm{NH}_{4}^{+}$per se does not inhibit hydrogenase activity and, in the presence of $\mathrm{H}_{2}$, synthesis of the enzyme is greatly induced. Thus, the inducible hydrogenase system of $P$. saccharophila resembles that of Aquaspirillum autotrophicum (Aragno \& Schlegel, 1978), Alcaligenes hydrogenophilus (Friedrich et al., 1984) and Rhizobium ORS 571 (de Vries et al., 1984), but differs from that of Azospirillum brasilense (Tibelius \& Knowles, 1983) and most strains of Paracoccus denitrificans (Nokhal \& Schlegel, 1980). In Rhodopseudomonas capsulata (Colbeau \& Vignais, 1983) the $\mathrm{H}_{2}$ evolved during $\mathrm{N}_{2}$ fixation is probably responsible for the stimulated hydrogenase expression in $\mathrm{N}_{2}$-fixing culture. In both $R$. capsulata (Colbeau \& Vignais, 1983) and $P$. saccharophila, expression of hydrogenase in both autotrophic and heterotrophic $\mathrm{NH}_{4}^{+}$-utilizing cultures provided with exogenous $\mathrm{H}_{2}$ suggests that hydrogenase is independent of nitrogenase expression.

Under carbon-limited conditions hydrogenase activity of Azotobacter chroococcum is consistently high (Partridge et al., 1980; Walker \& Yates, 1978). Likewise, we observed maximum hydrogenase activity when residual sucrose was low or nil. In the presence of $15 \mathrm{~mm}$ sucrose, the synthesis of hydrogenase was repressed but the activity of preformed enzyme was not inhibited. Other utilizable carbon substrates tested also repressed hydrogenase synthesis whereas those which were little or not at all utilized showed a negligible repressive effect. Similar behaviour is seen in Rhizobium japonicum (Maier et al., 1979). However, in Aquaspirillum autotrophicum (Aragno \& Schlegel, 1978), Rhizobium ORS 571 (de Vries et al., 1984) and $R$. japonicum strain JH (Graham et al., 1984), some utilizable carbon substrates do not repress enzyme formation. In the study of $R$. japonicum mutants, Merberg et al. (1983) found that a common element is involved in the regulation of hydrogenase by oxygen and by carbon substrates. In our study, it seems that sucrose repression of hydrogenase formation is independent of repression by $\mathrm{O}_{2}$. Catabolite repression involving cyclic AMP and possibly other effector molecules is implicated in malate-mediated repression of $\mathrm{H}_{2}$ uptake in $R$. japonicum (Lim \& Shanmugam, 1979; McGetrick et al., 1985). The discrepancies among these reports may indicate only the presence of different mechanisms by which carbon substrates regulate $\mathrm{H}_{2}$ oxidation. Nevertheless, $\mathrm{O}_{2}$ and carbon substrates may be essential coregulators especially in $\mathrm{O}_{2}$-sensitive hydrogenase systems.

The decline in activity in the presence of sucrose plus $\mathrm{Cm}$ was prevented by addition of $1 \mathrm{~mm}$ sodium azide, a known inhibitor of ATP production, but not by PMSF, a proteolysis inhibitor. Schlesier \& Friedrich (1981) reported inactivation of soluble hydrogenase in Alcaligenes eutrophus strain $\mathrm{H} 16$ when intact cells were exposed to $\mathrm{H}_{2} / \mathrm{O}_{2} / \mathrm{CO}_{2}$ atmosphere, and this 
inactivation was increased in the presence of $\mathrm{Cm}$; cells exposed to $\mathrm{H}_{2} / \mathrm{O}_{2}$ with 1 mM-sodium azide retained only about $10 \%$ of the activity of cells exposed to either air or $\mathrm{H}_{2}$ but $27 \%$ of the activity was retained in the presence of $5 \mathrm{~mm}$-sodium azide. However, addition of $2 \mathrm{mM}$-ATP to cell extracts did not enhance inactivation of hydrogenase and it was concluded that inactivation was due to superoxide radical anions produced by hydrogenase itself during catalysis. Our results seem to suggest that inactivation is ATP-supported and, as in A. eutrophus, is not due to simple proteolysis. Further study is needed to test this hypothesis.

Hydrogenase activity of $P$. saccharophila was not sensitive to $\mathrm{O}_{2}$ and in this respect resembles the $\mathrm{H}_{2}$ uptake system of Aquaspirillum autotrophicum, Alcaligenes eutrophus and Azospirillum amazonense (Aragno \& Schlegel, 1978; Fu \& Knowles, 1986; Wilde \& Schlegel, 1982) but differs from that of other diazotrophic bacteria such as Azospirillum brasilense and Azospirillum lipoferum (Fu \& Knowles, 1986; Pedrosa et al., 1982; Tibelius \& Knowles, 1983), and Rhizobium japonicum and its bacteroids (Maier et al., 1979; Ruiz-Arguëso et al., 1979). However, $18 \% \mathrm{O}_{2}$ partially repressed hydrogenase formation. Complete repression was reported in Aquaspirillum autotrophicum at $30 \% \mathrm{O}_{2}$ whereas enzyme synthesis occurred at $20 \% \mathrm{O}_{2}$ but at a much lower rate than at $2.5 \% \mathrm{O}_{2}$ (Aragno \& Schlegel, 1978).

Nitrogenase activity was maximal at a $\mathrm{pO}_{2}$ of 0.0025 to 0.005 atm and was almost completely inhibited at $0.05 \mathrm{pO}_{2}$ in common with many other aerobic $\mathrm{N}_{2}$-fixing bacteria (Barraquio et al., 1986; Fu \& Knowles, 1986; Tibelius \& Knowles, 1983). Unpublished data from late-exponential phase $\mathrm{N}_{2}$-fixing cultures showed that the presence or absence of $\mathrm{H}_{2}$ and thus of $\mathrm{O}_{2}$-dependent $\mathrm{H}_{2}$ uptake had no effect on the $\mathrm{O}_{2}$ tolerance of the nitrogenase. This is in agreement with data for Azospirillum brasilense (Pedrosa et al., 1982) but contrasts with Azotobacter chroococcum (Walker \& Yates, 1978) where oxidation of exogenous $\mathrm{H}_{2}$ afforded some protection for nitrogenase.

This work was supported by a grant to R.K. from the Natural Sciences and Engineering Research Council of Canada.

We thank Don Tito for initial help with the $\mathrm{H}^{3} \mathrm{H}$ uptake assay.

\section{REFERENCES}

Aragno, M. \& Schlegel, H. G. (1978). Physiological characterization of the hydrogen bacterium Aquaspirillum autotrophicum. Archives of Microbiology 116, 221-229.

Barraquio, W. L., Padre, B. C., JR, Watanabe, I. \& KNOWLES, R. (1986). Nitrogen fixation by Pseudomonas saccharophila Doudoroff ATCC 15946. Journal of General Microbiology 132, 237-241.

BERNDT, H. \& WöLFLE, D. (1978). Hydrogenase: its role as electron generating enzyme in the nitrogenfixing hydrogen bacterium Xanthobacter autotrophicus. In Hydrogenases: Their Catalytic Activity, Structure and Function, pp. 327-351. Edited by H. G. Schlegel \& K. Schneider. Göttingen: Goltze Verlag.

BONE, D. H. (1960). Localization of hydrogen activating enzymes in Pseudomonas saccharophila. Biochemical and Biophysical Research Communications 3, 211-214.

Bowien, B. \& Schlegel, H. G. (1981). Physiology and biochemistry of aerobic hydrogen-oxidizing bacteria. Annual Review of Microbiology 35, 405-452.

ChaN, Y. K., Nelson, L. M. \& KNowles, R. (1980). Hydrogen metabolism of Azospirillum brasilense in nitrogen-free medium. Canadian Journal of Microbiology 26, 1126-1131.

ColbeaU, A. \& Vignais, P. M. (1983). The membranebound hydrogenase of Rhodopseudomonas capsulata is inducible and contains nickel. Biochimica et biophysica acta 748, 128-138.
Dixon, R. O. D. (1972). Hydrogenase in legume root nodule bacteroids: occurrence and properties. Archiv für Mikrobiologie 85, 193-201.

Donawa, A. L., Ishaque, M. \& Aleem, M. I. H. (1971). Energy conversion in autotrophically-grown Pseudomonas saccharophila. European Journal of Biochemistry 21, 292-300.

DOUDOROFF, M. (1940). The oxidative assimilation of sugars and related substances by Pseudomonas saccharophila. Enzymologia 9, 59-72.

EMERICH, D. W., Ruiz-ArguËso, T., ChING, T. M. \& Evans, H. J. (1979). Hydrogen-dependent nitrogenase activity and ATP formation in Rhizobium japonicum bacteroids. Journal of Bacteriology 137, 153-160.

Friedrich, B., Friedrich, C. G., Meyer, M. \& SCHLEGEL, H. G. (1984). Expression of hydrogenase in Alcaligenes spp. is altered by interspecific plasmid exchange. Journal of Bacteriology 158, 331-333.

FU, C. \& KNOWLES, R. (1986). Oxygen tolerance of uptake hydrogenase in Azospirillum spp. Canadian Journal of Microbiology 32, 897-900.

Graham, L. A., Stults, L. W. \& Maier, R. J. (1984). Nitrogenase-hydrogenase relationships in Rhizobium japonicum. Archives of Microbiology 140, 243246.

Herbert, D., Phipps, P. J. \& Strange, R. E. (1971). Chemical analysis of microbial cells. Methods in Microbiology 5B, 209-344. 
LEE, S. B. \& WiLSON, P. W. (1943). Hydrogenase and nitrogen fixation by Azotobacter. Journal of Biological Chemistry 151, 377-385.

LIM, S. T. \& SHANMUGAM, K. T. (1979). Regulation of hydrogen utilization in Rhizobium japonicum by cyclic AMP. Biochimica et biophysica acta 584, 479 492.

Maier, R. J., Hanus, F. J. \& Evans, H. J. (1979). Regulation of hydrogenase in Rhizobium japonicum. Journal of Bacteriology 137, 824-829.

McGetrick, A. M., Goulding, C. F., Manian, S. S. \& O'GARA, F. (1985). Catabolite repression and role of cyclic AMP in $\mathrm{CO}_{2}$ fixation and $\mathrm{H}_{2}$ metabolism in Rhizobium spp. Journal of Bacteriology 163, 1282 1284.

Markwell, M. A. K., HaAs, S. M., Bieber, L. L. \& TOlBERT, N. E. (1978). A modification of the Lowry procedure to simplify protein determination in membrane and lipoprotein samples. Analytical Biochemistry 87, 206-210.

MerberG, D., O'HARA, E. B. \& MaIER, R. J. (1983). Regulation of hydrogenase in Rhizobium japonicum: analysis of mutants altered in regulation by carbon substrates and oxygen. Journal of Bacteriology 156, 1236-1242.

NokHAL, T.-H. \& Schlegel, H. G. (1980). The regulation of hydrogenase formation as a differentiating character of strains of Paracoccus denitrificans. Antonie van Leeuwenhoek 46, 143-155.

Palleroni, N. J. (1956). El metabolismo de los hidratos de carbono en Pseudomonas saccharophila. Ciencia e investigación 12, 468-474.

Palleroni, N. J. (1984). Genus I. Pseudomonas Migula. In Bergey's Manual of Systematic Bacteriology, vol. 1, pp. 141-199. Edited by N. R. Krieg. Baltimore: Williams \& Wilkins.

Partridge, C. D. P., W Alker, C. C., Yates, M. G. \& Postgate, J. R. (1980). The relationship between hydrogenase and nitrogenase in Azotobacter chroococcum: effect of nitrogen sources on hydrogenase activity. Journal of General Microbiology 119, 313319.
Pedrosa, F. O., Stephan, M., Döbereiner, J. \& YATES, M. G. (1982). Hydrogen-uptake hydrogenase activity in nitrogen-fixing Azospirillum brasilense. Journal of General Microbiology 128, 161-166.

PodzuWeit, H. G., SchNeIder, K. \& Schlegel, H. G. (1983). Autotrophic growth and hydrogenase activity of Pseudomonas saccharophila strains. FEMS Microbiology Letters 19, 169-173.

RuIz-ARguëso, T., EMERICH, D. W. \& EvaNS, H. J. (1979). Characteristics of the $\mathrm{H}_{2}$-oxidizing system in soybean nodule bacteroids. Archives of Microbiology 121, 199-206.

Salminen, S. O. \& Nelson, L. M. (1984). Role of uptake hydrogenase in providing reductant for nitrogenase in Rhizobium leguminosarum bacteroids. Biochimica et biophysica acta 764, 132-137.

SCHINK, B. \& ZEIKUS, J. G. (1984). Ecology of aerobic hydrogen-oxidizing bacteria in two freshwater lake ecosystems. Canadian Journal of Microbiology 30, 260-265.

SCHLESIER, M. \& FRIEDRICH, B. (1981). In vivo inactivation of soluble hydrogenase of Alcaligenes eutrophus. Archives of Microbiology 129, 150-153.

Tibelius, K. H. \& KNOWLES, R. (1983). Effect of hydrogen and oxygen on uptake hydrogenase activity in nitrogen-fixing and ammonium-grown $\mathrm{Azo}$ spirillum brasilense. Canadian Journal of Microbiology 29, 1119-1125.

DE VRies, W., Stam, H. \& Stouthamer, A. H. (1984). Hydrogen oxidation and nitrogen fixation in rhizobia, with special attention focused on strain ORS 571. Antonie van Leeuwenhoek 50, 505-524.

Walker, C. C. \& Yates, M. G. (1978). The hydrogen cycle in nitrogen-fixing Azotobacter chroococcum. Biochimie 60, 225-231.

Wilde, E. \& Schlegel, H. G. (1982). Oxygen tolerance of strictly aerobic hydrogen bacteria. Antonie van Leeuwenhoek 48, 131-143.

Wilhelm, E., BATtino, R. \& Wilcock, R. J. (1977). Low-pressure solubility of gases in liquid water. Chemical Reviews 77, 219-262. 